\title{
Haptoglobin and pig-major acute protein are increased in pigs with postweaning multisystemic wasting syndrome (PMWS)
}

\author{
Joaquim Segalés ${ }^{\mathrm{a} *}$, Carlos PIÑEIRO ${ }^{\mathrm{b}}$, Fermín LAMPREAVE $^{\mathrm{c}}$, \\ Miquel NOFRARÍAS ${ }^{\mathrm{a}}$, Enric MATEU ${ }^{\mathrm{a}}$, Maria CALSAMIGLIA ${ }^{\mathrm{a}}$, \\ Marta ANDRÉS ${ }^{\mathrm{c}}$, Joaquín MORALES ${ }^{\mathrm{b}}$, Matilde PIÑEIROc ${ }^{\mathrm{c}}$, \\ Mariano DOMINGO ${ }^{\mathrm{a}}$
}

\begin{abstract}
a Centre de Recerca en Sanitat Animal (CReSA), Departament de Sanitat i d'Anatomia Animals, Facultat de Veterinaria, Universitat Autònoma de Barcelona, 08193 Bellaterra, Barcelona, Spain b PigCHAMP Pro Europa, S.A., Grupo Proinserga, Segovia, Spain

c Departamento de Bioquímica y Biología Molecular y Celular, Facultad de Ciencias, Universidad de Zaragoza, Zaragoza, Spain
\end{abstract}

(Received 15 October 2003; accepted 8 December 2003)

\begin{abstract}
The objective of this study was to determine the serum concentration levels of selected acute phase proteins (APP), haptoglobin (HPT) and pig-major acute phase protein (pig-MAP), in postweaning multisystemic wasting syndrome (PMWS) affected pigs and PCV2-subclinically infected pigs. In a first study, a group of 15 eight-week-old conventional pigs from a PMWS affected farm were bled and a complete necropsy, histopathology and in situ hybridisation to detect PCV2 were performed. Based on the results, pigs were classified as suffering from PMWS $(n=10)$ or healthy animals $(n=5)$. In a second study, a group of 45 pigs from another PMWS affected farm were selected and bled at 3, 7, 12 and 28 weeks of age. The assessment of PCV2 infection status in these pigs was retrospectively done by PCV2 PCR in serum samples. Selected APP were measured in the serum of all studied pigs by means of radial immunodiffusion. Mean HPT and pig-MAP levels were significantly increased ( $p=0.004$ and $p=0.0006$ respectively) in PMWS-affected pigs when compared to levels found in healthy pigs $(2.52 \pm 0.88 \mathrm{mg} / \mathrm{mL}$ vs. $1.06 \pm 0.73 \mathrm{mg} / \mathrm{mL}$ for HPT and $3.81 \pm 1.53 \mathrm{mg} / \mathrm{mL}$ vs. $0.76 \pm 0.34 \mathrm{mg} / \mathrm{mL}$ for pig-MAP). In the second study, no significant difference in mean HPT and pig-MAP values were observed between PCV2 PCR positive and negative pigs of any age. However, both APP increased significantly with age in PCV2 PCR negative pigs. Altogether, the present results suggest that APP levels are significantly increased in pigs that develop PMWS, but not in animals with a PCV2 subclinical infection.
\end{abstract}

porcine circovirus type 2 (PCV2) / postweaning multisystemic wasting syndrome (PMWS) / acute phase proteins / haptoglobin / pig major acute phase protein (pig-MAP)

\section{INTRODUCTION}

The acute phase response (APR) in both humans and animals is defined as a non- specific reaction to tissue damage such as infection, inflammation, neoplasia and immunological disease $[3,16,23,33]$. The APR is a very complex reaction, involving

\footnotetext{
* Corresponding author: joaquim.segales@uab.es
} 
local and systemic effects. One of these effects corresponds to changes in the concentration of some plasma proteins, mainly synthesised in the liver, which are called acute phase proteins (APP). Some of these proteins increase their serum levels (positive APP) while others decrease (negative APP). The positive APP have been used in veterinary medicine to study the APR to inflammation and infection $[2,16,33]$.

Postweaning multisystemic wasting syndrome (PMWS) is a recently described disease caused by porcine circovirus type 2 (PCV2), which affects late nursery and fattening pigs $[1,4,37]$. The final diagnosis of PMWS is established based on three different criteria: (1) the presence of compatible clinical signs, (2) the presence of characteristic histopathological lesions in lymphoid tissues, and (3) the detection of PCV2 antigen or nucleic acid in the damaged lymphoid organs [40]. Major clinical findings of PMWS are growth retardation, respiratory distress and mortality $[18,30]$. The most relevant microscopic lesions are lymphocyte depletion and granulomatous inflammation in lymphoid tissues [11, 37]; in addition, affected pigs may potentially have granulomatous inflammation in almost all tissues $[21,37]$. Therefore, the pathological picture of PMWS has a marked inflammatory component and strongly suggests the alteration of APP profiles in affected pigs. This hypothesis has been preliminarily confirmed in one study where an increased serum haptoglobin (HPT) in chronically PMWS affected herds was observed [25].

Taking into account all the mentioned premises, the objective of the present work was to compare the serum concentration levels of HPT and pig-major acute phase protein (pig-MAP), two major porcine APP $[15,24]$, between PMWS affected pigs and PCV2-subclinically infected pigs, and to assess the utility of APP serum concentrations as an objective indicator for the evaluation of the individual and herd health.

\section{MATERIALS AND METHODS}

\subsection{Farms, pigs and assessment of PMWS/PCV2 infection}

In a first study, a group of 15 eight-weekold conventional pigs from a farm located in eastern Spain were used. The farm was seronegative to porcine reproductive and respiratory syndrome virus (PRRSV) and Aujeszky disease virus (ADV). No evidence of porcine pleuropneumonia, streptococcal meningitis, atrophic rhinitis or enzootic pneumonia was recorded at any age group of pigs on the farm based on clinical, serological and pathological examinations. The vaccination program for the sows included inactivated porcine parvovirus (PPV) and live $\mathrm{ADV} \mathrm{gE}^{-}$vaccines. PMWS had previously been diagnosed based on clinical signs, histopathological lesions in lymphoid tissues and detection of PCV2 [40]. Ten out of 15 pigs were selected, in a single farm visit, based on clinical signs compatible with PMWS, such as moderate growth retardation, paleness of the skin and dyspnea. These animals showed a wasting disease starting approximately one week before. Concomitantly, five healthy pigs from the same batch (same age and location in the farm as the other selected animals) were also selected. All pigs were bled by a cava cranial venipuncture and euthanised by means of a sodium pentobarbital overdose and a complete necropsy was performed. Tonsil, superficial inguinal lymph node and lung tissues were fixed by immersion in $10 \%$ neutral-buffered formalin, dehydrated, embedded in paraffin wax and sectioned at $4-\mu \mathrm{m}$. Tissue sections were stained with haematoxylin and eosin (HE). Correlative sections were also placed on silanecoated (3-[trietoxysilil]-propilamine) slides and PCV2 nucleic acid presence was tested by a previously described in situ hybridisation (ISH) technique [37]. Serum from each pig was stored at $-80{ }^{\circ} \mathrm{C}$ until analysis.

In a second study, a group of 45 pigs from a genetic nucleus farm located in central Spain was used. The farm was suffering 
from a severe outbreak of PMWS during a one-year period, initiated five months before the starting of the present sampling. The farm was shown to be seronegative to ADV $\mathrm{gE}$ protein and PRRSV. The vaccination programme of the sows included an ADV live vaccine, twice a year. Gilts were also vaccinated against $A D V$ (the same vaccine as for sows), and PPV and erysipelas (combined killed vaccine), twice during the gilt adaptation period. Fattening pigs did not receive any vaccine during the whole production period. No evidence of porcine pleuropneumonia, streptococcal meningitis, atrophic rhinitis or enzootic pneumonia was recorded at any age group of pigs on the farm based on clinical, serological and pathological examinations. The 45 pigs were selected from a larger group of 250 animals which were ear-tagged at three weeks of age and bled at 3, 7, 12 and 28 weeks of age. The studied population were pigs that did not show clinical signs compatible with PMWS during the whole study period, which were not slaughtered because they were selected as part of the future breeding stock for the genetic company. Serum from all 45 pigs was stored at $-80{ }^{\circ} \mathrm{C}$ until analysis. To assess the PCV2 infection status, a standard PCR to detect the virus [31] was applied on the serum of the 45 pigs at the selected ages.

\subsection{Acute phase protein determination in serum}

Two APP, HPT and pig-MAP, were measured in the serum of all studied pigs. The concentration of these proteins was determined by radial immunodiffusion [29] in $1 \%$ agarose gels containing specific rabbit polyclonal antisera and using a porcine serum as a secondary standard. The concentration of HPT and Pig-MAP in this serum was previously determined by radial immunodiffusion using the purified proteins $[15$, 24] as the primary reference standard. In these experimental conditions intra- and inter-assay coefficients of variation were lower than $5 \%$.

\subsection{Statistical analyses}

The data generated in both studies followed a normal distribution (Shapiro-Wilk, test with $p>0.05$ ). In the first study, data on APP serum levels were subjected to analysis of variance according to the general linear model (GLM) procedure using software of SAS [39] to compare pigs with no clinical signs of disease versus PMWS affected pigs. In the second study, relationships among APP serum levels of PCV2infected and non-infected pigs at selected ages (3, 7, 12 and 28 weeks of age) were analysed by the repeated measures model (MIXED) of SAS [39] and an LSMEANS follow-up test was used for comparison of means. Significance was set at $p<0.05$.

\section{RESULTS}

\subsection{First study: pigs with clinical signs of PMWS}

Gross lesions in PMWS affected pigs were characterised by the enlargement of lymph nodes $(n=7)$, non-collapsed, tanmottled lungs $(n=5)$, craneo-ventral pulmonary consolidation $(n=5)$, serous atrophy of the fat $(n=5)$ and thymus atrophy $(n=3)$. No gross lesions were observed in the healthy pigs. Histologically, mild to severe generalised lymphocyte depletion together with granulomatous inflammation was found in all diseased pigs. Other microscopic findings detected in PMWS pigs were interstitial pneumonia $(n=10)$, lymphohistiocytic hepatitis $(n=7)$ and interstitial nephritis $(n=6)$. No significant microscopic lesions were observed in any of the healthy pigs studied except for slight lymphocyte depletion in the lymphoid tissues of one pig.

All diseased pigs $(n=10)$ were positive to PCV2 by ISH, confirming the definitive diagnosis of PMWS. The amount of virus present in the lymphoid tissues (tonsil and inguinal lymph node) ranged from moderate to high in all animals. However, the ISH 
Table I. Haptoglobin (HPT) and pig-major acute protein (pig-MAP) concentrations $(\mathrm{mg} / \mathrm{mL})$ in 10 pigs with diagnosed PMWS and 5 healthy pigs.

\begin{tabular}{lccc}
\hline Pig No. & Health status & Pig-MAP & HPT \\
\hline 1 & PMWS & 3.65 & 3.56 \\
2 & PMWS & 2.53 & 2.03 \\
3 & PMWS & 2.66 & 2.04 \\
4 & PMWS & 3.65 & 2.69 \\
5 & PMWS & 3.35 & 2.04 \\
6 & PMWS & 6.71 & 3.26 \\
7 & PMWS & 4.83 & 1.50 \\
8 & PMWS & 5.43 & 4.18 \\
9 & PMWS & 3.95 & 2.17 \\
10 & PMWS & 1.39 & 1.70 \\
11 & Healthy & 0.63 & 0.82 \\
$12^{\mathrm{a}}$ & Healthy & 0.91 & 2.04 \\
13 & Healthy & 0.54 & 0.11 \\
14 & Healthy & 0.46 & 0.48 \\
15 & Healthy & 0.63 & 1.21 \\
\hline
\end{tabular}

a Pig which had minimal amounts of PCV2 nucleic acid in lymphoid tissues measured by in situ hybridisation.

in healthy pigs showed that four of them were negative to PCV2, and only one of these animals had low amounts of PCV2 nucleic acid in the follicular centres of the inguinal lymph node and tonsil (the same pig having slight lymphocyte depletion).
Individual results of HPT and pig-MAP serum levels are included in Table I. The levels of APP in diseased pigs were significantly higher than in healthy pigs ( $p$ values of 0.004 for HPT and 0.0006 for pig-MAP). Mean HPT levels were $2.52 \pm 0.88 \mathrm{mg} / \mathrm{mL}$ and $1.06 \pm 0.73 \mathrm{mg} / \mathrm{mL}$ in PMWS and healthy pigs, respectively, while pig-MAP levels were $3.81 \pm 1.53 \mathrm{mg} / \mathrm{mL}$ and $0.76 \pm$ $0.34 \mathrm{mg} / \mathrm{mL}$, respectively. The mean HPT and Pig-MAP levels of PMWS affected pigs were 2.38 and 5.01 greater values than healthy pigs.

\subsection{Second study: PCV2-subclinically infected pigs}

PMWS clinical signs started at eight weeks of age in the selected farm. The clinical picture at the farm level included wasting, paleness of the skin, respiratory distress and mortality. Eighty-three out of 250 (33.2\%) pigs died between 3 and 12 weeks of age. Sixty-seven of the dead pigs were necropsied; fifty-one of these pigs $(76.1 \%)$ were diagnosed as PMWS based on histological lymphoid lesions and detection of PCV2 by ISH.

The results of APP determinations and PCV2 PCR of the selected 45 pigs are summarised in Table II. Although the mean APP values (for both HPT and Pig-MAP) were increased in the PCV2 infected animals when compared with non-infected

Table II. Mean haptoglobin (HPT) and porcine major acute protein (pig-MAP) serum levels (mg/mL) and standard deviations in 45 pigs from a farm which suffered an acute outbreak of PMWS. For each age group, the number of pigs ( $n$ ) and the result from the PCR testing (positive/negative) are provided.

\begin{tabular}{lcclcc}
\hline & \multicolumn{2}{c}{ Pig-MAP } & & HPT \\
\cline { 2 - 3 } \cline { 5 - 6 } Age of pigs & PCV2 PCR positive & PCV2 PCR negative & & PCV2 PCR positive & PCV2 PCR negative \\
\hline 3 weeks & - & $0.86 \pm 0.44^{\mathrm{a}}(n=45)$ & - & $0.78 \pm 0.73^{\mathrm{a}}(n=45)$ \\
7 weeks & $1.29 \pm 0.79^{\mathrm{a}}(n=8)$ & $0.84 \pm 0.52^{\mathrm{a}}(n=37)$ & & $1.14 \pm 1.03^{\mathrm{a}}(n=8)$ & $1.10 \pm 0.95^{\mathrm{a}, \mathrm{b}}(n=37)$ \\
12 weeks & $1.50 \pm 1.32^{\mathrm{a}}(n=30)$ & $1.04 \pm 0.48^{\mathrm{a}, \mathrm{b}}(n=15)$ & & $1.99 \pm 0.76^{\mathrm{a}}(n=30)$ & $1.90 \pm 0.46^{\mathrm{b}}(n=15)$ \\
28 weeks & $1.85 \pm 1.51^{\mathrm{a}}(n=6)$ & $1.59 \pm 1.42^{\mathrm{b}}(n=39)$ & & $2.18 \pm 0.85^{\mathrm{a}}(n=6)$ & $1.59 \pm 0.73^{\mathrm{b}}(n=39)$ \\
\hline
\end{tabular}

a,b Indicate significant differences $(p<0.05)$ between age-groups of the same infectious status. 
pigs, no significant differences were observed between both groups of pigs at any age. On the contrary, both HPT and Pig-MAP concentrations in the serum increased significantly with age, but only in the non-PCV2 infected pigs (Tab. II).

\section{DISCUSSION}

Our first study showed that PMWS affected pigs had statistically significant increase in the serum concentrations of APP when compared with the ones found in age-matched healthy pigs. This indicates that both HPT and pig-MAP can be used as markers for the illness status of PMWS. These results are not surprising because the serum concentrations of these APP increase in pigs with inflammation [24, 33], and PMWS is probably one of the most representative pig diseases characterised by a systemic generalised inflammation [37], with marked changes of the cell populations which play a role in inflammation [10]. Taking into account that a disease status is considered a good indicator of poor welfare [5] and the fact that APP are objective indicators of non-specific disease, among other conditions $[6,16,33]$, the results of the first study suggest that APP can be used for the characterisation of the welfare status of farms with PMWS.

Only one pig from the healthy animals had serum HPT levels comparable with those of the diseased pigs. This animal was the one containing lower amounts of PCV2 nucleic acid in their lymphoid tissues, suggesting that subclinically infected pigs may have increased their levels of APP, as it has been suggested as plausible in other studies $[19,32]$. However, the pig-MAP serum level of the same animal, although slightly increased compared to the rest of healthy pigs, was considered normal; it is not known if the differences in these two APP kinetics during the APR could explain this situation. Taking into account the result of both APP, this animal could be considered a borderline between healthy and pathological pigs regarding PMWS. In fact, these low amounts of virus together with the slight lesions can be compatible with a subclinical PCV2 infection but also with the initial phases of PMWS [40].

Haematological and immunological parameters for the group of PMWS and healthy pigs have been studied previously [12]. Briefly, pigs suffering from PMWS showed severe alterations of haematological parameters (anaemia, lymphopenia with a decrease of CD8 T cells and B cells, monocytosis and neutrophilia), and alterations in the cytokine expression profiles characterised by an overexpression of IL10 in the thymus and a general decrease of cytokines IL-2, IL-4, IL-10, IL-12p40 and IFN- $\gamma$ in selected lymphoid organs (inguinal superficial and bronchial lymph nodes, spleen and tonsils). A statistical significant association was observed between the increase of pig-MAP serum levels and increased numbers of red blood cells and IL-10 in the thymus, and decreased values of mean corpuscular volume, serum iron (Fe), B cells and CD8 T cells in diseased animals; moreover, the increased levels of HPT were also significantly associated with the increase of IL-10 in the thymus, and decreased values of $\mathrm{Fe}$ and haemoglobin (data not shown). Considering that the anaemia observed in those animals has been associated to iron deficiency [12], it would not be surprising that the APR explains this finding since HPT is involved in $\mathrm{Fe}$ transportation by binding haemoglobin [33, 35], and its increase will imply a decrease in serum $\mathrm{Fe}$ and haemoglobin. However, it can not be discarded that the observed iron deficiency can also be related with chronic inflammatory disease with increased levels of IL-10 in the thymus [12], since this cytokine can induce the intracellular store of $\mathrm{Fe}[28]$ and also hyperferritinemia [42]. However, the implications of pig-MAP in haematological and immunological changes of PMWS are more difficult to assess since the physiological functions of this protein are not well defined yet. Pig-MAP or inter-alpha trypsin 
inhibitor heavy chain 4 (ITIH4), is considered a new member of the inter-alpha trypsin inhibitor (ITI) family [38]. This family is formed by structurally related plasma serine inhibitors involved in extracellular matrix stabilisation [8]. ITIH4, unlike other members of the ITI family, does not include bikunin (a kunitz-type protease inhibitor) in their composition and is therefore not a protease inhibitor. Pig-MAP/ITH4 has been shown to be expressed in the endometrium during the oestrous cycle and early pregnancy in pigs [14]. Recent studies suggest that the ITIH4 may act as an anti-inflammatory protein since it has been shown that this protein can inhibit actin polymerisation and phagocytosis of polymorphonuclear cells [9].

The longitudinal study in a group of 45 pigs did not show any significant differences with regards to APP serum concentrations when comparing PCV2 infected and non-infected by serum PCR (in a given age). It has been demonstrated that the result of PCR in serum for PCV2 is not adequate for diagnosing PMWS [7]. Furthermore, when screening pigs of different ages by this method, a very high number of animals are PCR positive despite having or not PMWS based on the previous commented diagnostic criteria [26, 41]. Therefore, although the studied pigs came from a farm suffering a severe PMWS outbreak, they represented a population that survived the disease period. Individual clinical signs were not recorded in these particular animals. It can not, however, be discarded that some of them developed a certain degree of non-detected clinical disease, since the APP values of some individuals were similar to those observed in the diseased pigs of the first study. It is possible that the lack of a significant difference between the groups, despite the trend towards an increase of APP in infected animals, was due to the high variability of these values in both PCV2 infected and non-infected pigs as confirmed by the wide standard deviation in each group for each studied APP. However, significant differences in APP serum concentration were observed among ages of non-PCV2 infected pigs. This result may indicate that both HPT and Pig-MAP serum levels increase with age, as has been previously suggested [36]. However, other studies have not shown any effect of age on the APP concentrations [32, 34] unless other situations occurring in these later productive phases such as subclinical infections, temperature oscillations in the farm and overcrowding may cause an increase in APP levels.

For the present studies, two farms with minimal pathogen microbism were chosen. The main reason for this was to discard the potential effects of viral and bacterial pathogens which have been demonstrated to cause an increase in serum APP, such as PRRSV, Pasteurella multocida, Bordetella bronchiseptica, Streptococcus suis and Actinobacillus pleuropneumoniae $[2,13,17$, $20,22,27]$. Therefore, the values obtained reflected the effect of PCV2-associated disease and discard the effect of other potential known diseases. In fact, if another unknown disease or infection had been present, it would have been logical that it could affect PMWS and PCV2-subclinically infected pig groups as well as non-PCV2 infected pigs.

In summary, the data from the present studies indicate that APP, such as HPT and pig-MAP, were significantly increased in pigs with diagnosed PMWS when compared to healthy age-matched pigs. However, PCV2 subclinically infected pigs did not show differences in HPT and pig-MAP serum concentrations when compared to age-matched, non-PCV2 infected animals. These latter results suggest that the increase of APP levels depend on the development of PMWS and not on infection with PCV2 alone. Further studies are needed to assess the potential differences between affected and non-affected farms and different pig ages to establish the usefulness of APP determination with regards to health status and the efficacy of PMWS control measures. 


\section{ACKNOWLEDGMENTS}

This work was partly funded by Projects QLRT-PL-199900307 from the European Commission and the 2-FEDER-1997-1341 from the I+D National Plan (Spain).

\section{REFERENCES}

[1] Allan G.M., Kennedy S., McNeilly F., Foster J.C., Ellis J.A., Krakowka S.J., Meehan B.M., Adair B.M., Experimental reproduction of severe wasting disease by co-infection of pigs with porcine circovirus and porcine parvovirus, J. Comp. Pathol. 121 (1999) 1-11.

[2] Asai T., Mori M., Okada M., Uruno K., Yazawa S., Shibata I., Elevated serum haptoglobin in pigs infected with porcine reproductive and respiratory syndrome virus, Vet. Immunol. Immunopathol. 70 (1999) 143148.

[3] Baumann H., Gauldie J., The acute phase response, Immunol. Today 15 (1994) 74-80.

[4] Bolin S.R., Stoffregen W.C., Nayar G.P., Hamel A.L., Postweaning multisystemic wasting syndrome induced after experimental inoculation of cesarean-derived, colostrum-deprived piglets with type 2 porcine circovirus, J. Vet. Diagn. Invest. 13 (2001) 185-194.

[5] Broom D.M., A review of animal welfare measurement in pigs, Pig News and Information 17 (1996) 109N-114N.

[6] Burger W., Fennert E.M., Pohle M., Wesemeier H., C-reactive protein - a characteristic feature of health control in swine, J. Vet. Med. A 39 (1992) 635-638.

[7] Calsamiglia M., Segalés J., Quintana J., Rosell C., Domingo M., Detection of porcine circovirus type 1 and 2 in serum and tissue samples of pigs with and without postweaning multisystemic wasting syndrome, J. Clin. Microbiol. 40 (2002) 1848-1850.

[8] Chen L., Mao S.J., McLean L.R., Powers R.W., Larsen W.J., Proteins of the inter-alphatrypsin inhibitor family stabilize the cumulus extracellular matrix through their direct binding with hyaluronic acid, J. Biol. Chem. 269 (1994) 28282-28287.

[9] Choi-Miura N.H., Takahashi K., Yoda M., Saito K., Hori M., Ozaki H., Mazda T., Tomita M., The novel acute phase protein, IHRP, inhibits actin polymerization and phagocytosis of polymorphonuclear cells, Inflamm. Res. 49 (2000) 305-310.
[10] Chianini F., Majó N., Segalés J., Domínguez J., Domingo M., Immunohistochemical characterisation of PCV2 associte lesions in lymphoid and non-lymphoid tissues of pigs with natural postweaning multisystemic wasting syndrome (PMWS), Vet. Immunol. Immunopathol. 94 (2003) 63-75.

[11] Clark E.G., Post-weaning multisystemic wasting syndrome, Proc. Am. Assoc. Swine Pract. 28 (1997) 499-501.

[12] Darwich L., Pié S., Rovira A., Segalés J., Domingo M., Oswald I.P., Mateu E., Cytokine mRNA expression profiles in lymphoid tissues of pigs naturally affected by postweaning multisystemic wasting syndrome, J. Gen. Virol. 84 (2003) 2117-2125.

[13] Francisco C.J., Shryock T.R., Bane D.P., Unverzagt L., Serum haptoglobin concentration in growing swine after intranasal challenge with Bordetella bronchiseptica and toxigenic Pasteurella multocida type D, Can. J. Vet. Res. 60 (1996) 222-227.

[14] Geisert R.D., Yelich J.V., Pratt T., Pomp D., Expression of an inter-alpha-trypsin inhibitor heavy chain-like protein in the pig endometrium during the oestrous cycle and early pregnancy, J. Reprod. Fertil. 114 (1998) 35-43.

[15] González-Ramón N., Alava M.A., Sarsa J.A., Piñeiro M., Escartin A., García-Gil A., Lampreave F., Piñeiro A., The major acute phase serum protein in pigs is homologous to human plasma kallikrein sensitive PK-120, FEBS Lett. 371 (1995) 227-230.

[16] Gruys E., Obwolo M.J., Toussaint M.J.M., Diagnostic significance of the major acute phase proteins in veterinary clinical chemistry: a review, Vet. Bull. 64 (1994) 1009-1018.

[17] Hall W.F., Eurell T.E., Hansen R.D., Herr L.G., Serum haptoglobin concentration in swine naturally or experimentally infected with Actinobacillus pleuropneumoniae, J. Am. Vet. Med. Assoc. 201(1992) 1730-1733.

[18] Harding J.C., Post-weaning multisystemic wasting syndrome, Proc. Am. Assoc. Swine Pract. 28 (1997) 503.

[19] Harding J.C., Baarsch M.J., Murtaugh M.P., Association of tumor necrosis factor and acute phase reactant changes with post-arrival disease in swine, J. Vet. Med. B 44 (1997) 405413.

[20] Heegaard P.M.H., Klausen J., Nielsen J.P., González-Ramón N., Piñeiro M., Lampreave F., Alava M.A., The porcine acute phase response to infection with Actionobacillus pleuropneumoniae. Haptoglobin, C-reactive protein, major acute phase protein and serum amyloid A protein are sensitive indicators of 
infection, Comp. Biochem. Physiol. B Biochem. Mol. Biol. 119 (1998) 365-373.

[21] Kennedy S., Moffett D., McNeilly F., Meehan B., Ellis J., Krakowka S., Allan G.M., Reproduction of lesions of postweaning multisystemic wasting syndrome by infection of conventional pigs with porcine circovirus type 2 alone or in combination with porcine parvovirus, J. Comp. Pathol. 122 (2000) 9-24.

[22] Knura-Deszczk S., Lipperheide C., Petersen B., Jobert J.L., Berthelot-Herault F., Kobisch M., Madec F., Plasma haptoglobin concentration in swine after challenge with Streptococcus suis, J. Vet. Med. B 49 (2002) 240-244.

[23] Kushner I., The phenomenon of the acute phase response, Ann. N.Y. Acad. Sci. 389 (1982) 40-48.

[24] Lampreave F., González-Ramón N., MartínezAyensa S., Hernández M.A., Lorenzo H.K., García-Gil A., Piñeiro A., Characterization of the acute phase serum protein response in pigs, Electrophoresis 15 (1994) 672-676.

[25] Lannou J., Bernard F., Amenna N., Morvan H., Auvigne V., Serum-haptoglobin concentration in herds chronically affected by PMWS, in: Proceedings of the 4th International Symposium on Emerging and $\mathrm{Re}$ emerging Diseases, 2003, pp. 213-214.

[26] Larochelle R., Magar R., D’Allaire S., Comparative serologic and virologic study of commercial swine herds with and without postweaning multisystemic wasting syndrome, Can. J. Vet. Res. 67 (2003) 114-120.

[27] Lauritzen B., Lykkesfeldt J., Skaanild M.T., Angen O., Nielsen J.P., Friis C., Putative biomarkers for evaluating antibiotic treatment: an experimental model of porcine Actinobacillus pleuropneumoniae infection, Res. Vet. Sci. 74 (2003) 261-270.

[28] Ludwiczek S., Aigner E., Theurl I., Weiss G., Cytokine-mediated regulation of iron transport in human monocytic cells, Blood 15 (2003) 4148-4154.

[29] Mancini G., Carbonara A.O., Heremans J.F., Immunochemical quantification of antigens by single radial immunodiffusion, Immunochemistry 2 (1965) 235-254.

[30] Quintana J., Segalés J., Rosell C., Calsamiglia M., Rodríguez-Arrioja G.M., Chianini F., Folch J.M., Maldonado J., Canal M., PlanaDuran J., Domingo M., Clinical and pathological observations on pigs with postweaning multisystemic wasting syndrome, Vet. Rec. 149 (2001) 357-361.

[31] Quintana J., Balasch M., Segalés J., Calsamiglia M., Rodríguez-Arrioja G.M., Plana-Duran J., Domingo M., Experimental inoculation of porcine circovirus type 1 (PCV1) and type 2 (PCV2) in rabbits and mice, Vet. Res. 33 (2002) 229-237.

[32] Petersen H.H., Ersboll A.K., Jensen C.S., Nielsen J.P., Serum-haptoglobin concentration in Danish slaughter pigs of different health status, Prev. Vet. Med. 54 (2002) 325335.

[33] Petersen H.H., Nielsen J.P., Heegard P.M.H., Application of acute phase protein measurements in veterinary clinical chemistry, Vet. Res. 35 (2004) 163-187.

[34] Piñeiro C., Estudio de las proteínas de fase aguda en el cerdo y su relación con los rendimientos productivos (Study of acute phase proteins in the pig and their relationship with production efficiency), Anaporc 233 (2003) 25-52.

[35] Putman F., Haptoglobin, in: Putman F.W. (Ed.), The plama proteins, Academic Press, 1975.

[36] Richter H., Haptoglobin bei haussäugetieren. III. Mitteilung: der haptoglobingehalt im blutplasma und-serum von widerkaüern und sweinen unter verschiedenen physiologischen bedingungen, Arch. Exp. Veterinaermed. 28 (1974) 505-519.

[37] Rosell C., Segalés J., Plana-Durán J., Balasch M., Rodríguez-Arrioja G.M., Kennedy S.M., Allan G., McNeilly F., Latimer K.S., Domingo M., Pathological, immunohistochemical, and in-situ hybridization studies of natural cases of post weaning multisystemic wasting syndrome (PMWS) in pigs, J. Comp. Pathol. 120 (1999) 59-78.

[38] Salier J.P., Rouet P., Raguenez G., Daveau M., The inter-alpha-inhibitor family: from structure to regulation, Biochem. J. 315 (1996) 1-9.

[39] SAS Institute, SAS/STAT Users' Guide, Version 8, SAS Institute Inc., Cary, NC, USA, 1999.

[40] Segalés J., Update on postweaning multisystemic wasting syndrome and porcine dermatitis and nephropathy syndrome diagnostics, J. Swine Health Prod. 10 (2002) 277-281.

[41] Sibila M., Calsamiglia M., Segalés J., Blanchard P., Badiella L., Le Dimna M., Jestin A., Domingo M., Use of a polymerase chain reaction assay and a ELISA to monitor porcine circovirus type 2 infection in pigs from farms with and without postweaning multisystemic wasting syndrome (PMWS), Am. J. Vet. Res. 65 (2004) 88-92.

[42] Tilg H., Ulmer H., Kaser A., Weiss G., Role of IL-10 for induction of anemia during inflammation, J. Immunol. 169 (2002) 22042209. 